\title{
Hazard assessment investigations due to recent changes in Triftgletscher, Bernese Alps, Switzerland
}

\author{
P. Dalban Canassy ${ }^{1}$, A. Bauder ${ }^{1}$, M. Dost ${ }^{2}$, R. Fäh ${ }^{1}$, M. Funk ${ }^{1}$, S. Margreth ${ }^{3}$, B. Müller ${ }^{\dagger}$, and S. Sugiyama ${ }^{4}$ \\ ${ }^{1}$ Laboratory of Hydraulics, Hydrology and Glaciology (VAW), ETH Zürich, C8092 Zürich, Switzerland \\ ${ }^{2}$ Chemnitzer Werkstoffmechanik GmbH, Otto-Schmerbach-Str. 19, 09117 Chemnitz, Germany \\ ${ }^{3}$ WSL Institut for Snow and Avalanche Research (SLF), 7260 Davos Dorf, Switzerland \\ ${ }^{4}$ Institute of Low Temperature Science, Hokkaido University, Kita-19 Nishi-8, Sapporo, 060-0819 Japan \\ $\dagger$ deceased, July 2004
}

Received: 16 December 2010 - Revised: 21 April 2011 - Accepted: 17 June 2011 - Published: 4 August 2011

\begin{abstract}
The details and the consequences of the recent retreat of Triftgletscher (Gadmertal, Bernese Alps, Switzerland) have been investigated. Geodetic volume changes indicate a strong decrease since 1929 while the position of the terminus remained practically unchanged until 1990. The role played by calving in the tongue retreat running from 2000 to 2006 is confirmed by means of a mass balance model including a calving criterion. Results show that without calving, it would have taken two years longer for the lake to form than has been observed. The consequences of the ensuing tongue destabilization are surveyed, first with an ice avalanche model and second with a hydraulic study of the potential impulse wave triggered by the impact of the falling ice mass in the lake. Results point out that ice avalanches with volumes greater that $1 \cdot 10^{6} \mathrm{~m}^{3}$ will flow into the lake and that in the worst scenario, a discharge of $400 \mathrm{~m}^{3} \mathrm{~s}^{-1}$ is expected to reach the endangered area in Gadmertal $11 \mathrm{~min}$ after the break-off. In order to detect surface motion precursors to such ice avalanches, a photographic monitoring system was installed. The results indicate seasonal variations with peak velocity in summer and no significant change during the other months. Spectacular velocity increases were not observed so far.
\end{abstract}

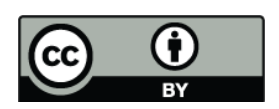

Correspondence to: P. Dalban Canassy (dalban@vaw.baug.ethz.ch)

\section{Introduction}

Triftgletscher is located between the Gadmer and Hasli valleys in the Bernese Alps in Switzerland (Fig. 1). It has a length of $5.1 \mathrm{~km}$, an area of $15 \mathrm{~km}^{2}$, an estimated ice volume of $1.3 \mathrm{~km}^{3}$ (Farinotti et al., 2009) and its altitude range extends from 1651 to $3380 \mathrm{~m}$ a.s.l. Note that the altitude of the terminus of Triftgletscher is one of the lowest in the Alps. Between 2350 and $2000 \mathrm{~m}$ a.s.l. it flows over a $35^{\circ}$ steep section towards the relatively flat tongue (Fig. 2, left). The glacier snout lies in a basin, which is bordered on the north side by a riegel (Fig. 2, right). The water drains of the basin through a narrow canyon deeply incised in the riegel. Over the last $15 \mathrm{yr}$ Triftgletscher has retreated substantially from the riegel and a proglacial lake containing $5 \cdot 10^{6} \mathrm{~m}^{3}$ water (Grischott et al., 2010) has progressively formed in the glacier forefield (Fig. 3).

Proglacial lakes are likely to represent serious hazards, for instance when they are located in unstable terrains (Vallon, 1989). In the case of Triftgletscher, one of the risks is induced by the calving of numerous pieces of ice during lake formation, which are likely to form a natural dam in the riegel region. In this context, the modelling of the terminus retreat appears relevant regarding the information it provides about how fast the lake forms. Moreover, because of the glacier retreat and especially the thinning of the lower flat tongue, the stability of the steep section behind it is affected. The consequence will be an increased portability of large ice avalanches from the steep section. The recent intense

Published by Copernicus Publications on behalf of the European Geosciences Union. 


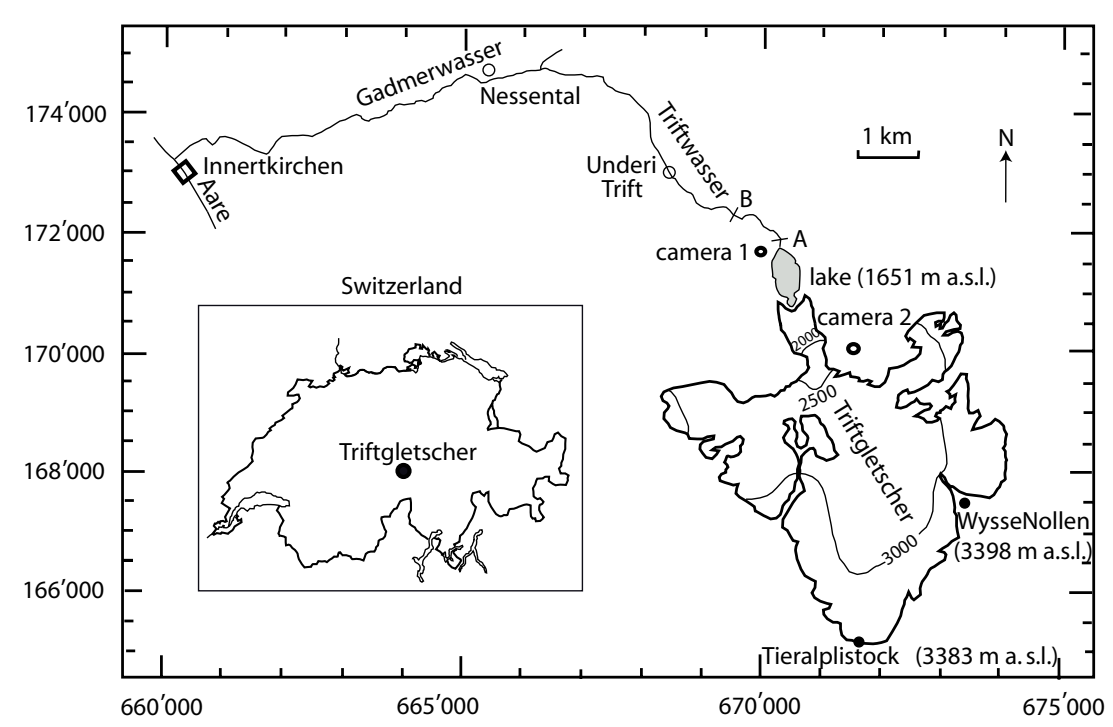

Fig. 1. Map of Triftgletscher with the locations of 2 automatic cameras.
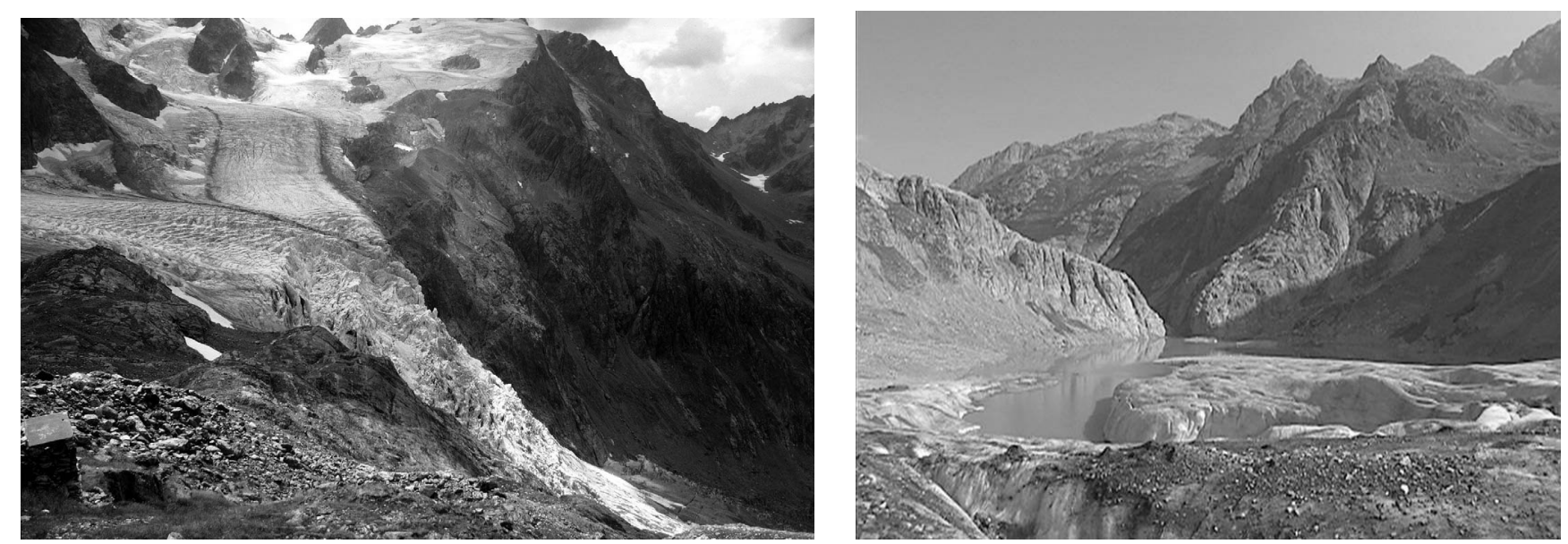

Fig. 2. Steep part of Triftgletscher in $2003\left(35^{\circ}\right.$, left $)$ and the riegel with the narrow gorge through which Triftwasser drains the basin $(2004)$ (photos M. Funk).

glacier thinning of the lower tongue $\left(6-10 \mathrm{~m} \mathrm{a}^{-1}\right)$ has aggravated the situation further because the runout path of the ice avalanches has become steeper. The result could be ice avalanches with several million $\mathrm{m}^{3}$ of ice plunging into the lake. Studies on the avalanche dynamics and hydraulics of lakewater have shown that ice avalanches with more than one million $\mathrm{m}^{3}$ of ice could generate dangerous flood waves, thus posing a threat to the inhabitants of Gadmertal.

This paper is organised as follow: the changes in Triftgletscher since 1861 are presented first and the glacier terminus retreat is then explained using a mass balance model coupled with a calving criterion, followed by a discussion of the likelihood of large ice avalanches occuring at Triftgletscher. Then the results from ice avalanche dynamics calculations are presented and the consequences of ice avalanches plunging into the lake in the context of a hydraulic study are discussed. Finally, we present the ongoing monitoring program for early warning and the results obtained so far.

\section{Changes in Triftgletscher since 1861}

It was possible to reconstruct the changes in Triftgletscher since 1861 on the basis of old maps and aerial photographs from different years. Information about the data used to infer the glacier changes is given in Table 1. Volume changes since 1929 have been assessed using digitized old maps and photogrammetric methods. 

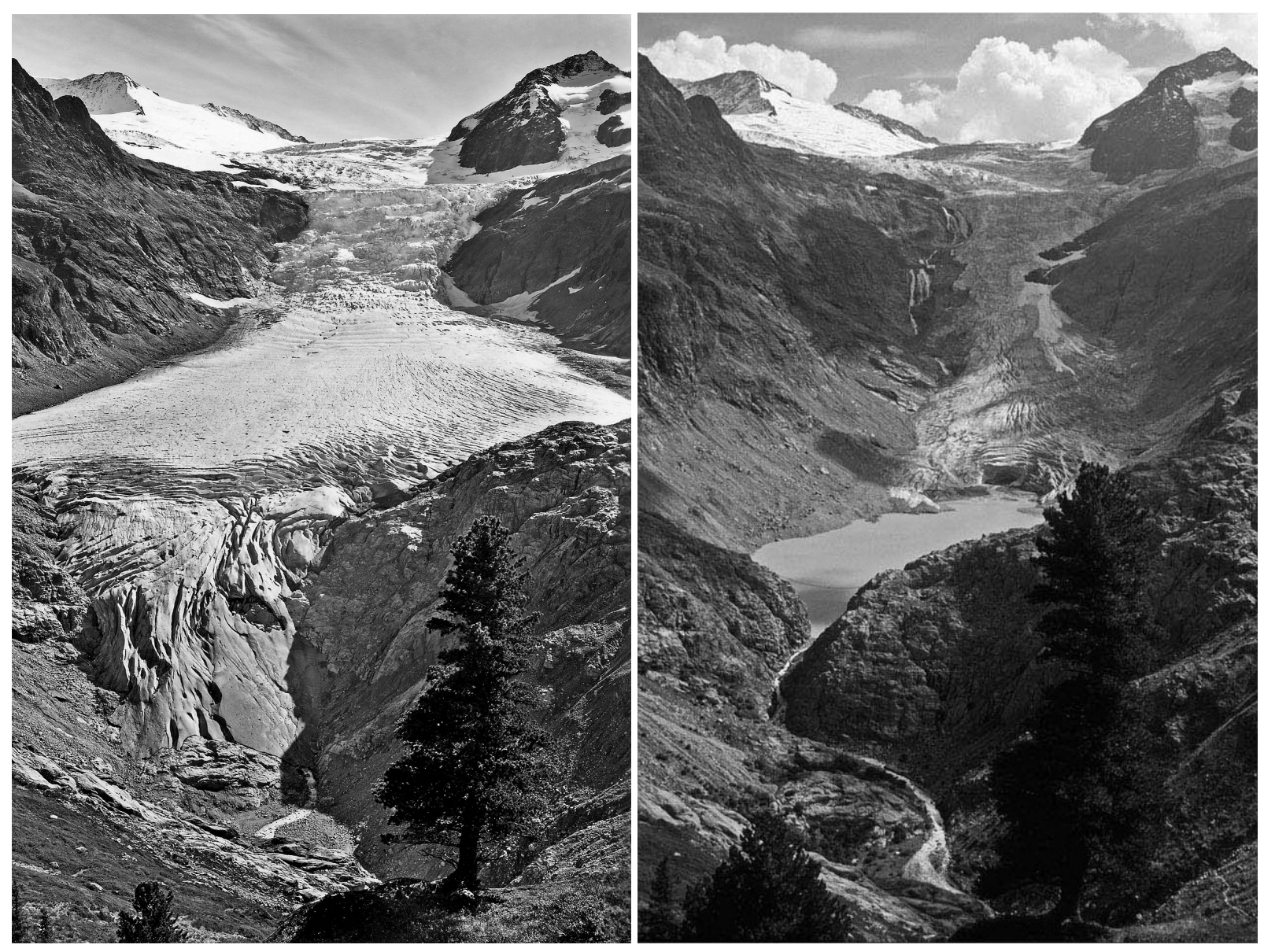

Fig. 3. Tongue of Triftgletscher in 1948 and 2006 (photos: archive Gesellschaft für Ökologische Forschung (http://www.gletscherarchiv.de) and F. Funk-Salamí).

\subsection{Photogrammetric survey}

\subsubsection{Method}

The high accuracy digital elevation models (DEMs) we use in this survey are based on photogrammetrical evaluation of aerial photographs, in a spatial resolution of $25 \mathrm{~m}$ (Bauder et al., 2007). The aerial photographs were acquired between mid-August and mid-October (Table 1). Geodetic volume changes were derived by assessing the elevation differences $(\Delta Z)$ between two given DEMs.

\subsubsection{Uncertainty assessment}

The reliability of the photogrammetric survey results directly adresses the question of the uncertainty associated with each photogrammetric calculation. According to Huss et al. (2009), the uncertainty in such geodetic methods comes from three principal error sources: (i) the orientation and the geolocation of the individual aerial photographs which lead to errors of $\pm 0.2-0.5 \mathrm{~m}$, (ii) the elevation information for single points whose contribution to the total uncertainty is $\pm 0.1 \mathrm{~m}$ because it is randomly distributed (Thibert et al., 2008) and (iii) the interpolation to unmeasured gridpoints which induces an uncertainty of $\pm 0.05-0.5 \mathrm{~m}$ (Bauder et al., 2007). In order to take into account the different error sources, we compute for each studied interval a $\sigma_{\text {period }}$ characterizing the uncertainty associated with the geodetic volume changes calculation between $\mathrm{DEM}_{1}$ and $\mathrm{DEM}_{2}$ (Huss et al., 2009) (Eq. 1):

$\sigma_{\text {period }}=\frac{1}{\Delta t} \sqrt{\sigma_{\text {DEM }_{1}}^{2}+\sigma_{\text {DEM }_{2}}^{2}}$,

where $\Delta t$ is the period duration in years and $\sigma_{\mathrm{DEM}}$ the uncertainty of each DEM. The reliability of each geodetic volume change is assessed by comparing $\sigma_{\text {period }}$ with the mean of the calculated elevation differences $(\overline{\Delta Z})$. The values of both parameters are given in Table 2 . We can see that for all the studied periods, $\sigma_{\text {period }}$ is significantly smaller than the associated $\overline{\Delta Z}$ value, which indicates that the derived geodetic volume changes are meaningful. In the following, the geodetic volume change uncertainty concerning one given studied period is computed using the associated glacier surface change and $\sigma_{\text {period }}$. 
Table 1. Database used to generate digital elevation models (DEMs) of Triftgletscher.

\begin{tabular}{lllll}
\hline Data & Date & Source & Coverage & Processing \\
\hline map 1:50 000 (Equidist = $30 \mathrm{~m})$ & 1861 & Siegfried map & whole glacier & digitizing contour lines \\
map 1:50000 (Equidist = 20 m & $1929-1936$ & official map & whole glacier & digitizing contour lines \\
aerial photos & $25-08-1959$ & swisstopo & whole glacier & photogrammetry \\
aerial photos & $18-08-1970$ & swisstopo & lower part & photogrammetry \\
aerial photos & $05-09-1980$ & swisstopo & lower part & photogrammetry \\
aerial photos & $15-09-1980$ & swisstopo & whole glacier & photogrammetry \\
aerial photos & $15-08-1986$ & swisstopo & lower part & photogrammetry \\
aerial photos & $20-08-1990$ & swisstopo & whole glacier & photogrammetry \\
aerial photos & $13-10-1995$ & swisstopo & whole glacier & photogrammetry \\
aerial photos & $24-08-2000$ & swisstopo & whole glacier & photogrammetry \\
aerial photos & $23-08-2001$ & swisstopo & lower part & photogrammetry \\
aerial photos & $13-09-2002$ & swisstopo & lower part & photogrammetry \\
aerial photos & $04-09-2003$ & swisstopo & whole glacier & photogrammetry \\
aerial photos & $28-07-2004$ & swisstopo & lower part & photogrammetry \\
aerial photos & $14-09-2005$ & swisstopo & lower part & photogrammetry \\
aerial photos & $05-09-2006$ & swisstopo & lower part & photogrammetry \\
aerial photos & $09-09-2008$ & swisstopo & whole glacier & photogrammetry \\
\hline
\end{tabular}

Table 2. $\sigma_{\text {period }}$ and $\overline{\Delta Z}$ for the geodetic volume changes calculations.

\begin{tabular}{lll}
\hline $\begin{array}{l}\text { Periods } \\
\text { of study }\end{array}$ & $\begin{array}{l}\sigma_{\text {period }} \\
\left(\mathrm{m} \mathrm{a}^{-1}\right)\end{array}$ & $\begin{array}{l}\overline{\Delta Z} \\
\left(\mathrm{~m} \mathrm{a}^{-1}\right)\end{array}$ \\
\hline $1929-25 / 08 / 1959$ & \pm 0.023 & -0.46 \\
$25 / 08 / 1959-15 / 09 / 1980$ & \pm 0.018 & +0.26 \\
$15 / 09 / 1980-20 / 08 / 1990$ & \pm 0.040 & -0.59 \\
$20 / 08 / 1990-13 / 10 / 1995$ & \pm 0.077 & -0.90 \\
$13 / 10 / 1995-24 / 08 / 2000$ & \pm 0.082 & -0.72 \\
$24 / 08 / 2000-04 / 09 / 2003$ & \pm 0.132 & -1.05 \\
$24 / 08 / 2003-09 / 09 / 2008$ & \pm 0.079 & -0.95 \\
\hline
\end{tabular}

\subsection{Volume changes}

Figure $4 \mathrm{a}$ shows the cumulative length changes (averaged along the terminus) and the volume changes since 1929, from data indicated in Table 3. After a retreat of more than $1.6 \mathrm{~km}$ from 1861 to 1950 , the position of the glacier terminus remained practically unchanged until 1990. A dramatic retreat of Triftgletscher started after 1990, accelerated by calving (see survey below) in the newly formed proglacial lake after the year 2000 (Fig. 5). Since 2006, the glacier tongue is no longer in contact with the lake and therefore the retreat rate is expected to decrease in the future. The cumulative ice volume loss in the period 1929-2006 amounts to almost $0.5 \mathrm{~km}^{3}$ (38\% of the estimated actual ice volume; Farinotti et al., 2009). The rate of ice volume loss has increased considerably since 1980 , reaching values between $-0.01 \pm 0.0006 \mathrm{~km}^{3} \mathrm{a}^{-1}$ and
$-0.017 \pm 0.002 \mathrm{~km}^{3} \mathrm{a}^{-1}$ (Fig. 4b). It is interesting to compare the rates of ice volume change in the accumulation and ablation areas separately (the division is drawn at the contour line $2500 \mathrm{~m}$ a.s.1., Fig. 1) (Fig. 4c). Whereas between 1960 and 1980 the ice volume increased in the upper part at a rate of $+0.006 \pm 0.0002 \mathrm{~km}^{3} \mathrm{a}^{-1}$, in the lower part it decreased by $-0.002 \pm 0.00002 \mathrm{~km}^{3} \mathrm{a}^{-1}$ during the same period. In the following period 1980-1990, this rate decreased to $-0.009 \pm 0.0006 \mathrm{~km}^{3} \mathrm{a}^{-1}$ in the upper part while it reached $-0.001 \pm 0.00006 \mathrm{~km}^{3} \mathrm{a}^{-1}$ in the lower part. In the following years, the ice volume of the whole glacier decreased and the ice loss was particularly pronounced in the lower part $\left(-0.007 \pm 0.0001\right.$ to $-0.009 \pm 0.00009 \mathrm{~km}^{3} \mathrm{a}^{-1}$ from 1990 to 2005). Figure 6 illustrates the changes in the longitudinal profile of the lower part since 1936. Ice volume changes show that between 1960 and 1980, the glacier mass increase was particularly strong. Between 1980 and 1990, the upper part was affected by a strong mass loss while the rate of volume change in the lower part increased slightly. This mass imbalance suggests an important ice flow from the upper to the lower part in the latter period. Afterwards, both the whole glacier and the lower part lost mass while the rate of volume changes in the upper part increased, indicating a progressive mass rearrangement within the glacier.

\section{Effect of the lake on glacier retreat}

\subsection{Goal of the study}

By modelling the glacier retreat using a simple mass balance model coupled with a calving model, we aim to assess the role played by calving when the lake formed. Indeed, an 
Table 3. Surface areas $\left(\mathrm{km}^{2}\right)$ for the whole glacier $(S)$ and for its upper $\left(S_{\mathrm{u}}\right)$ and lower part $\left(S_{\ell}\right) . \Delta V$ : corresponding ice volume changes $\left(\mathrm{km}^{3}\right)$.

\begin{tabular}{rrrrrrr}
\hline year & $S$ & $\Delta V$ & $S_{\mathrm{u}}$ & $\Delta V_{\mathrm{u}}$ & $S_{\ell}$ & $\Delta V_{\ell}$ \\
\hline 1929 & 18.697 & - & 16.109 & - & 2.587 & - \\
1959 & 10.938 & -0.238503 & 9.224 & -0.046331 & 1.713 & -0.192172 \\
1980 & 16.945 & 0.076030 & 15.471 & 0.113483 & 1.474 & -0.037453 \\
1990 & 16.354 & -0.099623 & 14.904 & -0.089642 & 1.449 & -0.009981 \\
1995 & 16.236 & -0.076287 & 14.863 & -0.042049 & 1.373 & -0.034238 \\
2000 & 15.734 & -0.057870 & 14.706 & -0.024826 & 1.028 & -0.033044 \\
2003 & 15.337 & -0.050387 & 14.541 & -0.023994 & 0.796 & -0.026393 \\
2006 & 14.662 & -0.073421 & 14.213 & -0.055994 & 0.449 & -0.017427 \\
\hline
\end{tabular}
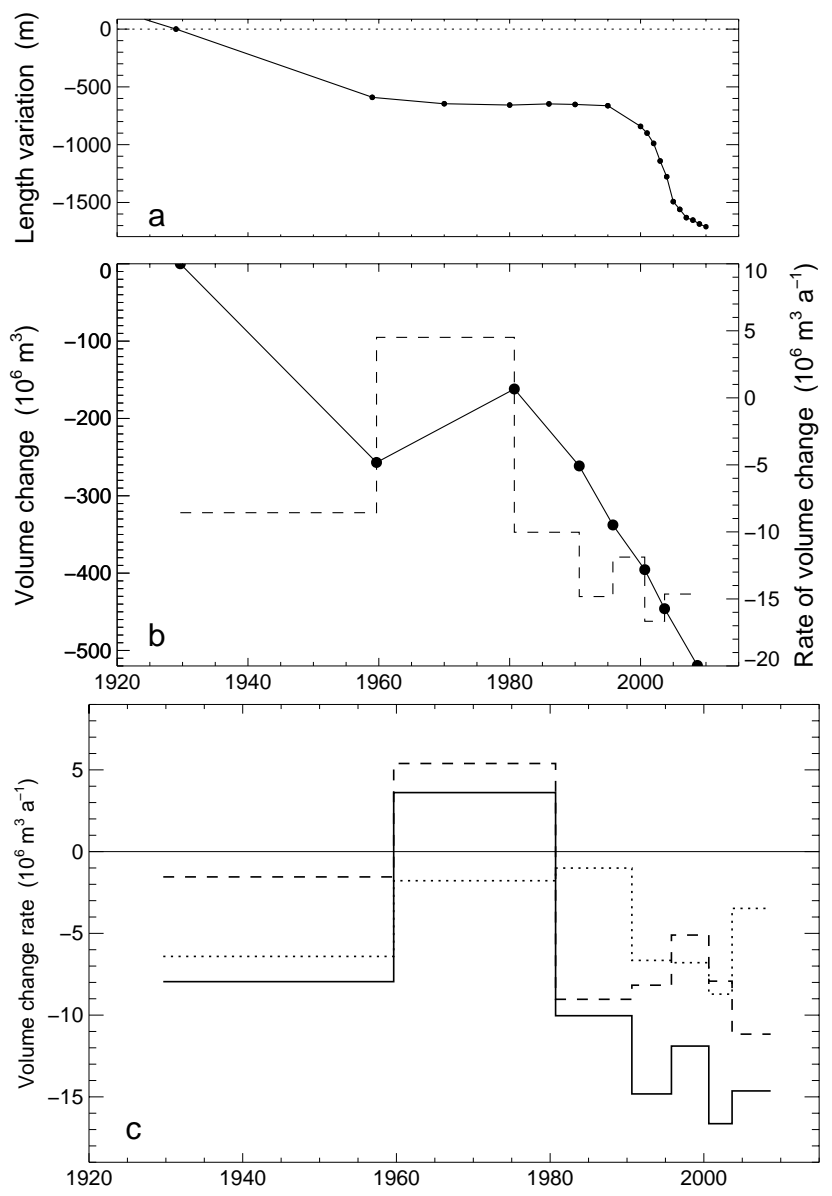

Fig. 4. Cumulative length (a); volume changes (solid line) and rate of volume change (dashed line) of Triftgletscher since 1929 (b); rates of volume change for the whole glacier (solid line), the upper part (dashed line) and the lower part (dotted line) (c).

important question regarding glaciers ending in lakes is to what extent the water contact influences their advance or retreat. It is well known that iceberg calving can be a very efficient ablation mechanism, permitting a much higher rate of mass loss than surface melting alone (Van der Veen, 1996; Vieli et al., 2001). We consider the dynamics of the tongue as negligible, which is reasonable given that the ice velocities measured in 2003 in this area were lower than $10 \mathrm{~m} \mathrm{a}^{-1}$ (Müller, 2004). We also consider that the totality of the ice was grounded in August 2000. The evolution of the lake surface from 2000 to 2006 is documented by ortho-photos (Fig. 5) taken every year in summer and by DEMs derived from the photogrammetric treatment of each photograph. The mass balance model is based on temperature and precipitation data. The lake bathymetry (Fig. 7a) was obtained from a reflection seismic survey aiming at the determination of the sediment layer thickness at the lake bottom (Grishott et al., 2010) in July 2009. The associated errors are estimated as $10 \%$.

\subsection{Calving rate definition and flotation level}

The calving rate $u_{\mathrm{c}}$ is defined as the volume of ice that breaks-off from the glacier terminus, per unit time and per unit of vertical area (Paterson, 1994, p. 376; Vieli et al., 2001). It is expressed by ice velocity $u_{\mathrm{i}}$ at the terminus minus the rate of change at the terminus position $L$ (Eq. 2) :

$u_{\mathrm{c}}=u_{\mathrm{i}}-\frac{d L}{\mathrm{~d} t}$.

Based on observations on Columbia Glacier (Meier and Post, 1987), Van der Veen (1996) proposed a flotation model to describe this phenomenon in the case of tidewater glaciers. In this model, the terminus of the glacier retreats to the position where the ice thickness $h$ approaches the flotation height by an amount $h_{\mathrm{o}}$. The critical thickness $h_{\mathrm{c}}$ at the terminus is then given by Eq. 3:

$h_{\mathrm{c}}=\frac{\rho_{\mathrm{w}}}{\rho_{\mathrm{i}}} d+h_{0}$,

where $\rho_{\mathrm{w}}$ is the density of the sea water, $\rho_{\mathrm{i}}$ the density of the glacier ice and $d$ the water depth. Once the ice thickness at a given point of the terminus reaches $h_{\mathrm{c}}$, the ice portion between this point and the calving front floats and can be 

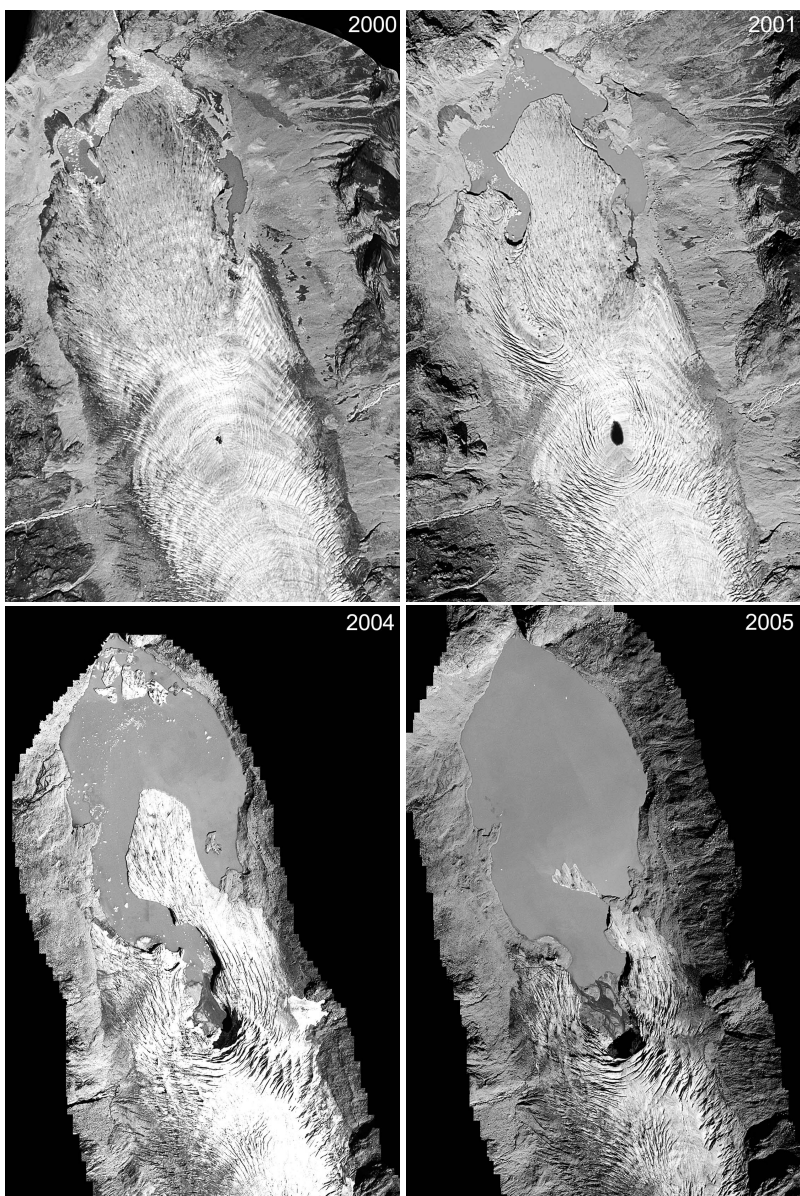

Fig. 5. Orthophotos of the glacier terminus from 2000 to 2006.

likely to calve when it can no longer resist the induced buoyancy force. The application of this calving criterion to lake ending glaciers has to be considered cautiously. First because such glaciers differ from tidewater glaciers because of lower velocities and calving speed. Second because they can sustain floating tongues for long periods prior to the onset of calving phases (Warren et al., 2001; Boyce et al., 2007). In this study, we propose to apply a flotation model to explain the retreat of the Triftgletscher terminus. For that, we chose the flotation level $h_{\mathrm{c}}=\frac{\rho_{\mathrm{w}}}{\rho_{\mathrm{i}}} d$ (with $\rho_{\mathrm{w}}=1000 \mathrm{~kg} \mathrm{~m}^{-3}$ and $\rho_{\mathrm{i}}=900 \mathrm{~kg} \mathrm{~m}^{-3}$ ) as calving criterion, assuming that it is only governed by surface ablation and setting $h_{0}$ to 0 . This implies that as soon as the elevation of a surface point behind the calving front becomes equal to $h_{\mathrm{c}}$, the portion between that point and the glacier terminus is assumed to calve and is removed. The limits of such an assumption are discussed with the analysis of the results.

\subsection{The mass balance model}

The terminus area, which lies between 1651 and $1700 \mathrm{~m}$ a.s.l., is discretized using a $25 \times 25 \mathrm{~m}$ mesh.
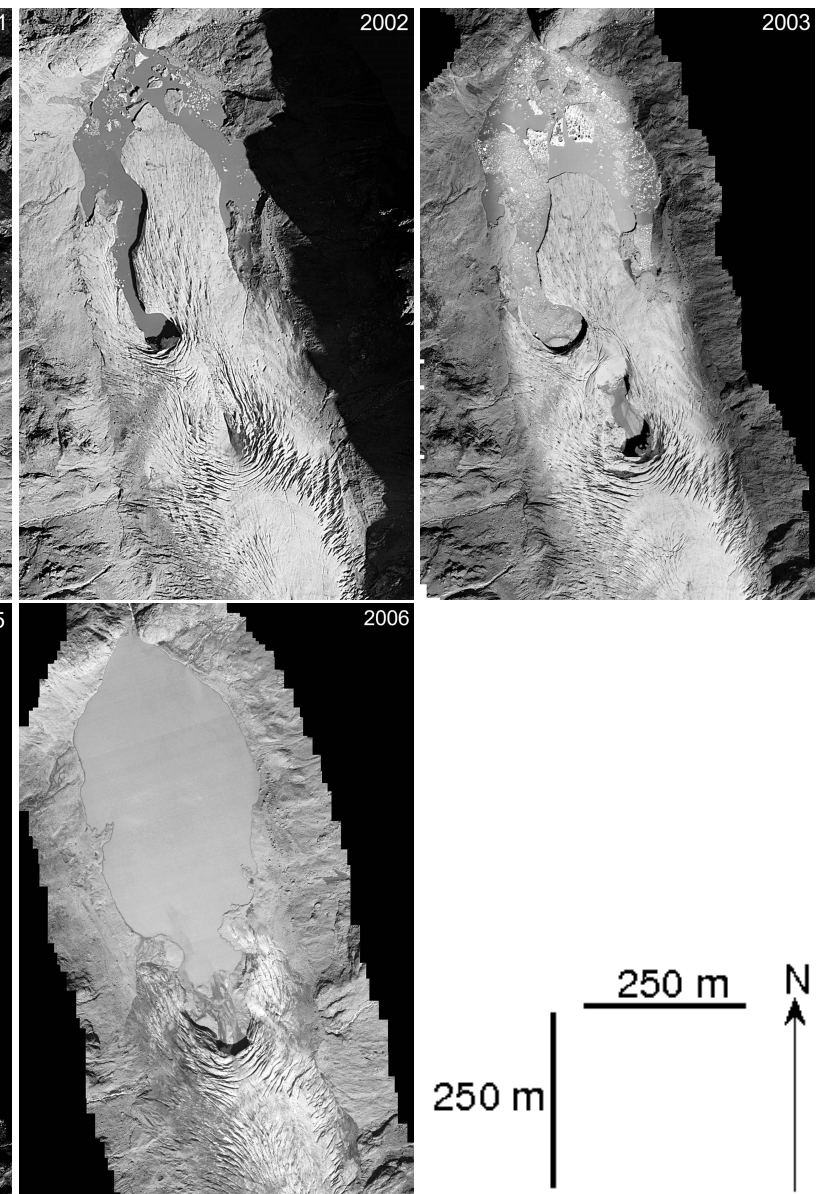

For every node, the daily specific mass balance is calculated using a temperature-index melt and accumulation model (Hock, 1999) based on a linear relation between melt rate and positive air temperature (Ohmura, 2001). Daily temperature and precipitation data are required as input. The surface melt rate $M\left(\mathrm{~m} \mathrm{~d}^{-1}\right)$ is calculated as

$$
M=\left(\begin{array}{ll}
F_{\mathrm{melt}} \cdot T & T>0 \\
0 & T \leq 0
\end{array}\right),
$$

where $F_{\text {melt }}\left(\mathrm{m} \mathrm{d}^{-1}{ }^{\circ} \mathrm{C}^{-1}\right)$ stands for a melt factor which corresponds to the amount of snow or ice melted per positive degree. The temperature and precipitation data are obtained from the Grimsel MeteoSwiss station (1980 m a.s.l). Temperatures are adjusted using a lapse rate of $0.006^{\circ} \mathrm{C} \mathrm{m}^{-1}$ (Vincent, 2002). The precipitation values are extrapolated from the collected data using a positive gradient $c_{\text {precip }}$ determined during the model calibration. A threshold temperature of $0{ }^{\circ} \mathrm{C}$ distinguishes snow from rainfall. In the following, we apply the model on time intervals running from one DEM of the terminus to the next in the following year, from 2000 to 2006. The reliability of the DEMs and of the derived geodetic volume changes is validated as it has 
Table 4. Melt factors $\left(\mathrm{m} \mathrm{d}^{-1}{ }^{\circ} \mathrm{C}^{-1}\right), c_{\text {precip }}$ values, $\sigma_{\text {period }}$ and $\overline{\Delta Z}$ for the periods studied.

\begin{tabular}{cccccc}
\hline Period of study & $\begin{array}{c}F_{\text {melt }} \\
\text { (ice) }\end{array}$ & $\begin{array}{c}F_{\text {melt }} \\
(\text { snow })\end{array}$ & $c_{\text {precip }}$ & $\begin{array}{c}\sigma_{\text {period }} \\
\left(\mathrm{m} \mathrm{a}^{-1}\right)\end{array}$ & $\begin{array}{c}\overline{\Delta Z} \\
\left(\mathrm{~m} \mathrm{a}^{-1}\right)\end{array}$ \\
\hline $24 / 08 / 2000-23 / 08 / 2001$ & 0.0063 & 0.0044 & 0.09 & \pm 0.40 & 11.6 \\
$23 / 08 / 2001-13 / 09 / 2002$ & 0.0063 & 0.0044 & 0.1 & \pm 0.47 & 12.7 \\
$13 / 09 / 2002-04 / 09 / 2003$ & 0.0061 & 0.0044 & 0.03 & \pm 0.41 & 9.3 \\
$04 / 09 / 2003-28 / 07 / 2004$ & 0.0061 & 0.0044 & 0 & \pm 0.44 & 4.8 \\
$28 / 07 / 2004-14 / 09 / 2005$ & 0.0061 & 0.0044 & 0 & \pm 0.35 & 5.7 \\
$14 / 09 / 2005-05 / 09 / 2006$ & 0.0061 & 0.0044 & 0 & \pm 0.41 & 2.0 \\
\hline
\end{tabular}

been done above (see Sect. 2.1.2) using values of $\sigma_{\text {period }}$ and $\overline{\Delta Z}$ shown in Table 4 . The calibration of the mass balance model is performed in 2 steps: (i) $F_{\text {melt }}$ are first determined for the periods 2001-2002 and 2002-2003, using surface ablation measurements performed in these two years between June and September (Müller, 2004). The values 0.0063 and $0.0061 \mathrm{~m} \mathrm{~d}^{-1}{ }^{\circ} \mathrm{C}^{-1}$ are obtained, respectively. (ii) The mass balance model is applied to the other periods, using the 2002 melt factor for 2000-2001 and the 2003 factor for 20032004, 2004-2005 and 2005-2006 and $c_{\text {precip }}$ is tuned to fit the associated geodetic volume changes. Results for the different years are shown in Table 4. For snow-melt, a melt factor equal to $0.0044 \mathrm{~m} \mathrm{~d}^{-1}{ }^{\circ} \mathrm{C}^{-1}$ was used (Vincent, 2002).

On the basis of this calibration, we applied the flotation model in the following way: for one given period, an initial elevation corresponding to the surface topography of the first day was fixed for every point. This initial topography was then modified on a daily time step according to the model. We modelled the tongue retreat from 2000 to 2006 considering the calving effect (case 1) and surface melting only (case 2). We also conducted this modelling year by year, from 2000 to 2006, to demonstrate how the calving influences the formation of the lake and to discuss the limits of the calving criterion assumption. A given point is considered as removed when its elevation falls below the flotation level $h_{\mathrm{c}}$, as in case 1 , or when the ice thickness becomes lower than $0.15 \mathrm{~m}$, as in case 2. Concerning each of the used DEMs between from 2000 to 2006 , we consider an uncertainty of $\pm 0.1 \mathrm{~m}$.

\subsection{Results}

\subsubsection{Assessment of the calving effect on the tongue re- treat}

Figures $8 \mathrm{a}$ and $8 \mathrm{~b}$ show modelling results of the tongue retreat between 2000 and 2006. The melted ice volume, corresponding in both cases to the surface bounded by the thick white line, is $0.120 \mathrm{~km}^{3}$ in case 1 and $0.08 \mathrm{~km}^{3}$ in case 2 . The modelling for case 1 accounts for $89 \%$ of the ice tongue retreat, whereas case 2 explains only $59 \%$ of it. This result
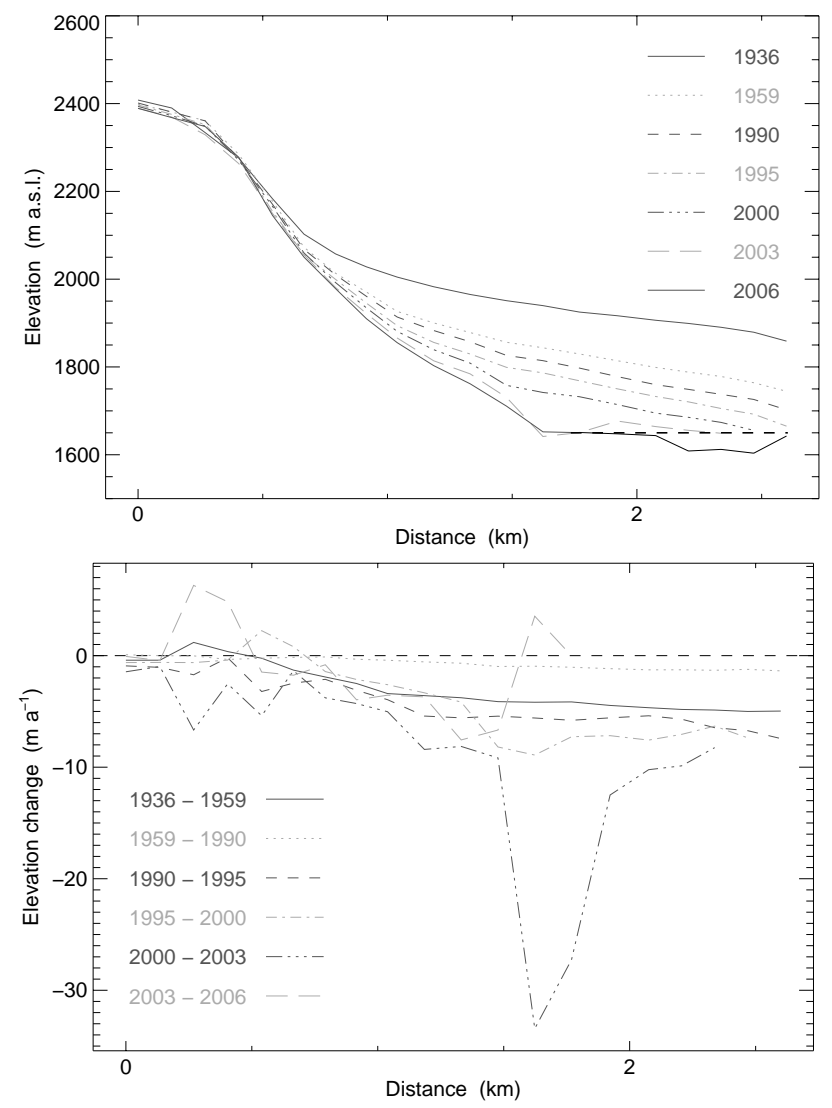

Fig. 6. Longitudinal profiles (above) and rate of elevation changes (below) of the lower part of Triftgletscher since 1936.
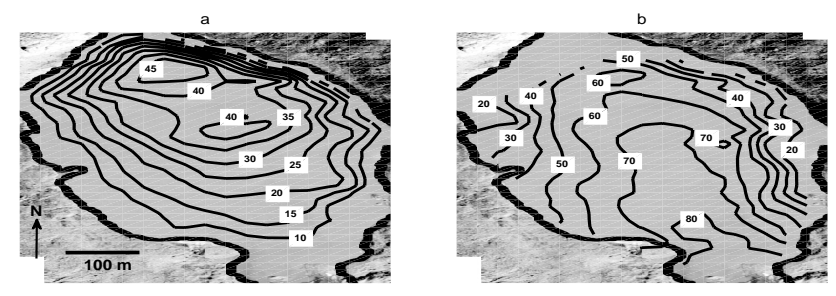

Fig. 7. Lake bathymetry (m) (a) and ice thickness distribution (m) on 20 August 2000 (b); the photograph in the background corresponds to the state of the lake in 2009; the thick black line indicates the lake bank.

highlights the role played by calving on the glacier retreat. The remaining glacier area in case 2 corresponds to ice thicknesses ranging from 70 to $80 \mathrm{~m}$ (see Fig. 7b) in 2000, and in 2006 still exhibits values ranging from 1 to $20 \mathrm{~m}$. Our results show that with surface melting alone, the ice mass in the lake area would have disappeared two years later (August 2008).

\subsubsection{Yearly results with the calving model and limits of the chosen calving criterion}

Yearly results with the calving model are shown in Fig. 9. The circles indicate where the flotation level $h_{\mathrm{c}}$ was reached 

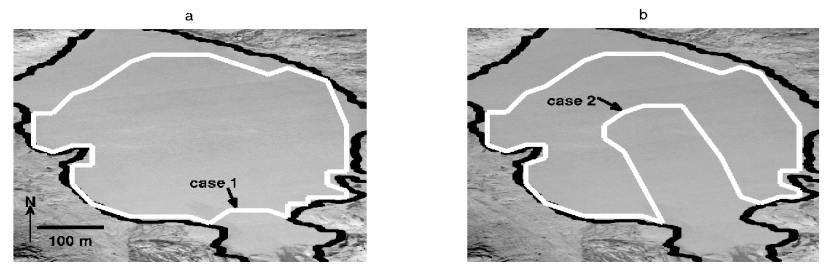

Fig. 8. Modelled deglaciated area (thick white line) with the calving criterion (case 1) (a) and with surface melting alone (case 2) (b) from 2000 to 2006; the photograph in the background corresponds to the state of the lake in 2006; the thick black line indicates the lake bank.

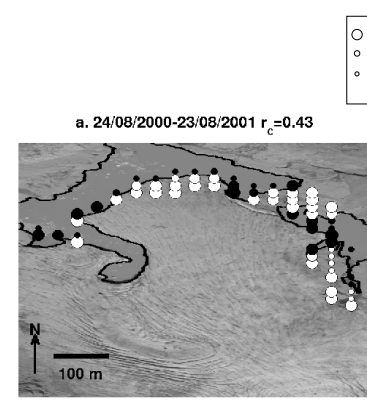

$$
\begin{gathered}
200<t_{t} \\
100<t_{t}^{t}<200 \\
t_{f}<100 \\
\text { (days) }
\end{gathered}
$$
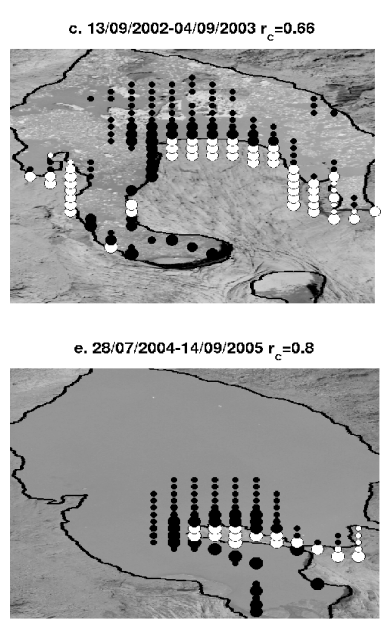

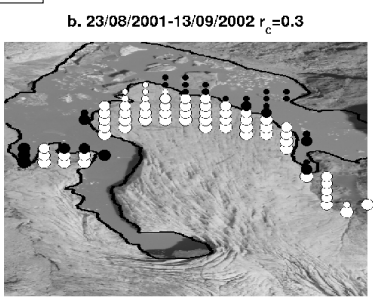

d. 04/09/2003-28/07/2004 $r_{c}=0.52$

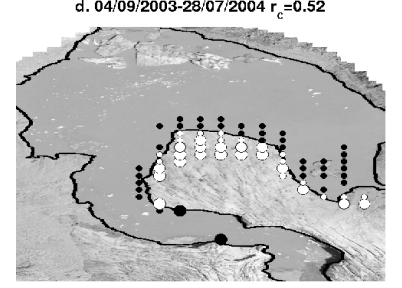

f. $14 / 09 / 2005-05 / 09 / 2006 r_{c}=0.68$

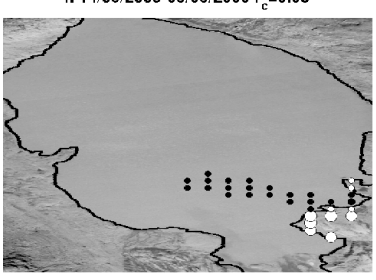

Fig. 9. Results of modelled glacier retreat from 2000 to 2006; circles denote points likely to calve, black circles denote points which calved, white circles denote points where ice is still present at the end of the considered time interval; $t_{\mathrm{f}}$ indicates the time a point requires to reach flotation level; $r_{\mathrm{c}}$ is the flotation model relevance.

during the considered time interval. Their radius indicates the time $\left(t_{\mathrm{f}}\right)$ needed to reach flotation level. The black circles indicate where the ice calved and the white circles where the ice is still present at the end of the considered time interval, i.e. where the calving model prediction is not verified. The relevance of the flotation model to explain the glacier retreat by calving is thus expressed by the ratio $r_{\mathrm{c}}=\frac{\sum \text { black circles }}{\sum \text { white circles }}$, $r_{\mathrm{c}}=1$ corresponding to the best suitability.

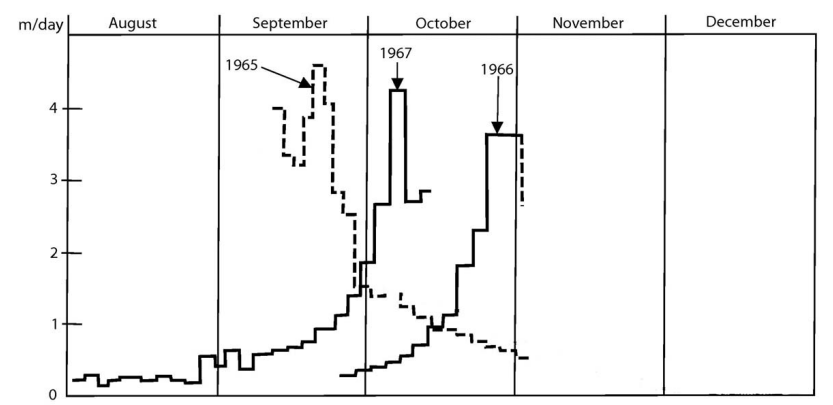

Fig. 10. Glacier motion following the 1965 active phase at Allalingletscher (dashed line) and active phases measured the next two years (solid lines) (Röthlisberger, 1981).

We first observe that the calving model is in general able to reproduce the observed glacier retreat. However, discrepancies can be noticed. First, on both sides of the glacier tongue, where the ice retreated faster than predicted by the calving model. For the east side, the presence of many crevasses favoured surface melting and desintegration of the glacier tongue. Evidences of high subglacial melt rates due to preferred basal water flow path could be observed on the west side. Because the water depths decrease and the ice thicknesses increase towards the south (Fig. 7a and b), the predicted times for calving $t_{\mathrm{f}}$ generally increase towards the south. In all years the observed glacier retreat is slower than predicted. The mismatch (lowest $r_{\mathrm{c}}$-values) is greatest in the years 2000-2001 and 2001-2002 (Fig. 9a and b), when a significant number of points sustain the flotation without calving failure.

Similar observations of floating tongue sustainment were made by Boyce et al. (2007) on the lake-calving glacier Mendenhall (Alaska, USA). The authors showed that the terminus was at flotation for two years before a calving event was observed in summer 2004, and explained this stable state because of the accomodation of the existing buoyant stress. Both lateral stability and back pressure provided by the bed geometry played a role, and the authors concluded that the final calving event was not triggered by the seasonal variations in thinning rate and in the lake level but by rapid perturbations in the lake level at a several days time scale. According to the bathymetry shown in Fig. 7a, no substancial back pressure is expected in the case of Triftgletscher. Moreover, the points where flotation is sustained are mainly located far from the banks, which reduced the influence of the lateral stability. The observed discrepancies mostly concern points associated with $t_{\mathrm{f}}$ values higher than 200 days, which implies that the flotation level is approached progressively in these cases. With regard to that, we suggest that the bending stresses accompanying the flotation setting up increase too slowly and may be relaxed by ice creep. The buoyant stress is therefore accomodated as one goes along and rapid calving failure is prevented (Boyce et al., 2007). 


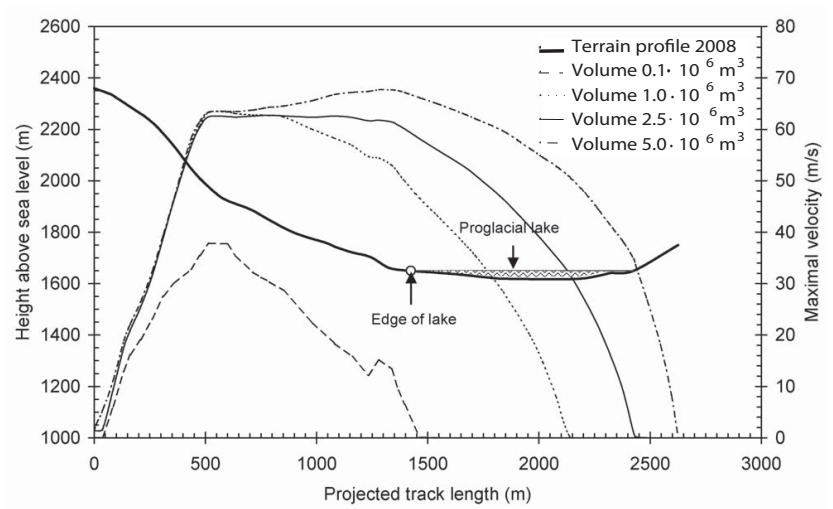

Fig. 11. Longitudinal profile of the expected surface geometry of the Triftgletscher tongue in 2008, with maximal flow velocities for the several ice-avalanche volume scenarios calculated with AVAL$1 \mathrm{D}$.

This points out the limits of the chosen calving criterion. Indeed, if the impact of the time delays induced by the possible flotation sustainment is minimized in results from studies running for several years, we see here that our criterion appears not to be able to reproduce in a precise way the glacier terminus retreat at a yearly time scale. Despite these discrepancies, the observed retreat of the tongue of Triftgletscher between 2000 and 2006 would have occurred two years later in the absence of calving. Calving is therefore an important factor to take into account when a glacier is retreating in a region where the glacier bed is overdeepened.

\section{Ice avalanche history}

Since the tragic Mattmark catastrophe (Allalingletscher in Valais, Switzerland, 30 August 1965), it is known that a major portion of a moderately steep (around $30^{\circ}$ slope) glacier tongue can become destabilized and release an ice avalanche. In this case, $2 \cdot 10^{6} \mathrm{~m}^{3}$ of the glacier tongue slid down a rock slope of about $27^{\circ}$ over a vertical distance of $400 \mathrm{~m}$ and continued an additional $400 \mathrm{~m}$ across the flat bottom of the valley, claiming 88 victims at the Mattmark construction site. Intensive glaciological studies were undertaken immediately after the catastrophe in order to safeguard the rescue operation and the construction work in the following years. It was shown that the avalanche was released during a period of enhanced bed slip (called "active phase") that started 2-3 weeks earlier (Röthlisberger, 1981). Measurement of 1965 showed the end of the active phase, while those from 1966 and 1967 indicated a surface motion acceleration during summer ending without break-off (Fig. 10). This rapid motion can be referred to as a surge-like movement or a build-up and discharge process. It consists of phases of intensive bed slip, alternating with quiescent phases with a relatively constant motion around $0.1 \mathrm{~m} \mathrm{~d}^{-1}$. Similar events occurred at Glacier

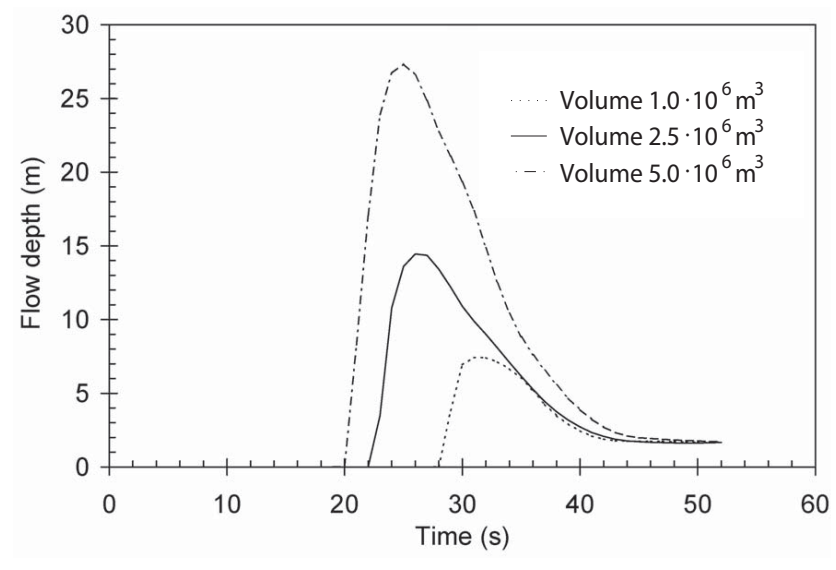

Fig. 12. Time plot of the flow depth at the position of the edge of the proglacial lake, for the surface geometry of Triftgletscher in 2008 calculated with AVAL-1D.

du Tour (France, 14 August 1949; Vivian, 2001) and Rhonegletscher (Valais, Switzerland; 23 July 1943; Raymond et al., 2003). These examples show that parts of a temperate glacier flowing on a steep slope (so called "ramp-type glacier") can sometimes fall as ice avalanches that devastate the valley floor far below the level of the glacier tongue. In the case of the $35^{\circ}$ Triftgletscher, this means that a sudden release of a substantial ice mass from the steep zone should be seriously considered. The exact timing of such icefalls is in most cases associated with a mechanical threshold that is approached through relatively slow evolution of the glacier over months to years. However, achieving a precise prediction of such an event is still a long way off. If the runout of an ice avalanche reaches the lake, a so-called impulse wave will be generated and propagated towards the valley. The magnitude of such a wave depends on the volume and the velocity of the ice avalanche plunging into the lake. In the following section, the runout and the dynamics of ice avalanches starting from the steep zone is investigated as a function of the ice volume released. On the basis of these results, the generation and the propagation of the subsequent impulse waves will be analyzed.

\section{Ice avalanche dynamics}

The goals of the ice avalanche dynamics study were to determine the minimal volume of an ice avalanche required to reach the proglacial lake and to calculate the amount of ice, the speed and flow depth of large ice avalanches with volumes between 1 and $5 \cdot 10^{6} \mathrm{~m}^{3}$ flowing into the lake. There are no dynamic models explicitly developed for the calculation of ice avalanches. In practice, topographical models (Alean, 1984) and dynamic models developed for snow avalanches (Margreth and Funk, 1999) are applied. As the validation of such models for the calculation of ice 
avalanches is complex, the results have to be interpreted carefully. For the present study, we applied AVAL-1D (Christen et al., 2002), a quasi one-dimensional, hydraulics-based, depth-averaged continuum model. It tracks the motion of the avalanche (velocities and snow heights) from initiation to runout. The main input parameters are the topography, the area and the thickness of the ice avalanche and the friction coefficients (dry friction $\mu$ and turbulent friction $\xi$ ). In the case of Triftgletscher, we assumed a ramp-type failure below the elevation of $2350 \mathrm{~m}$ a.s.l. According to the assumed scenarios, a 20 to $65 \mathrm{~m}$ thick and 120 to $480 \mathrm{~m}$ long ice mass might slide off. The width was assumed to be $200 \mathrm{~m}$. The mean inclination of the glacier bed is around $35^{\circ}$. AVAL1D employs a Voellmy-fluid law. This law divides avalanche flow resistance into the dry coulomb-type friction $\mu$ and a viscous resistance turbulent friction $\xi$ which varies with the square of the flow velocity (Bartelt et al., 1999). The friction parameters $\mu$ and $\xi$ depend on the avalanche volume, the terrain roughness and the snow type, which means that the ice volume is much more relevant for the calculation than the exact geometry of the detached ice mass. These parameters are usually specified according to the Swiss Guidelines for avalanche runout calculations (Salm et al., 1990), and were calibrated on the runout distance and velocity of observed real avalanches. Dry snow avalanches with large volumes $\left(>60000 \mathrm{~m}^{3}\right)$ flowing over smooth terrain have a much smaller friction than small, wet snow avalanches flowing through a terrain with a high roughness. For an extremely dry snow avalanche with a volume of more than $60000 \mathrm{~m}^{3}$ and a smooth terrain, $\mu$ and $\xi$-values of 0.16 and $2500 \mathrm{~m} \mathrm{~s}^{-2}$, respectively, are recommended.

An ice avalanche has higher friction than a snow avalanche. For Triftgletscher we therefore applied $\mu=0.2$ and $\xi=1750 \mathrm{~m} \mathrm{~s}^{-2}$, assuming that the ice avalanche is flowing over snow-covered terrain. For the "best-case" scenario we increased the friction $(\mu=0.35$ and $\xi=1000)$ for the very crevassed part of the track. In this part of the track, a loss of mass can be expected. However, large avalanches can erode and entrain additional ice masses. We performed avalanche dynamics calculations for the geometry of Triftgletscher in 2003 and 2008. In 2008 the runout zone above the lake became $3^{\circ}$ steeper and $200 \mathrm{~m}$ shorter because of glacier retreat, in comparison with 2003. The width of the avalanche in the runout zone is assumed to be $300 \mathrm{~m}$. The maximal altitude drop from the release area to the proglacial lake is around $700 \mathrm{~m}$. Figure 11 shows the flow velocities along the longitudinal profile calculated with AVAL-1D. The maximum calculated velocity is $67 \mathrm{~m} \mathrm{~s}^{-1}$. The main results of the calculations are summarized in Table 5 .

According to the results of the avalanche dynamics calculations and a careful interpretation of the data, we assume that an ice avalanche does not reach the proglacial lake if the detached ice volume is less than $0.2 \cdot 10^{6} \mathrm{~m}^{3}$ for the surface geometry of Triftgletscher in 2003 , and $0.1 \cdot 10^{6} \mathrm{~m}^{3}$ for the situation in 2008. If the detached ice volumes are greater than

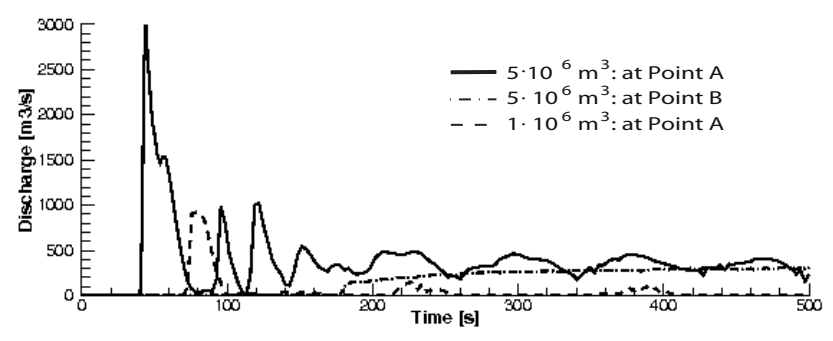

Fig. 13. Discharge in the canyon (position A) and $800 \mathrm{~m}$ downstream (position $B$ ) for ice release of 1 and $5 \times 10^{6} \mathrm{~m}^{3}$.

$1 \cdot 10^{6} \mathrm{~m}^{3}$, the avalanche plunges into the lake at high velocity. More than $90 \%$ of the avalanche mass with a volume of $5 \cdot 10^{6} \mathrm{~m}^{3}$ flows into the lake. In this case, the immersion time into the lake is about $20 \mathrm{~s}$ with an intermediate flow depth of $7 \mathrm{~m}$. We estimated the flow density of the ice avalanches to be between 400 and $500 \mathrm{~kg} \mathrm{~m}^{-3}$.

To check the plausibility of the calculations, we compared our results with those from the Mattmark ice avalanche of 1965 (Röthlisberger, 1981) using the reach of the ice release. The reach of an ice avalanche is described with the so called average slope $\alpha$. It is the slope of a line which starts at the top of the zone of release and ends at the farthest point of the deposit (Alean, 1984). There the reach of the ice avalanche with a volume of $2 \cdot 10^{6} \mathrm{~m}^{3}$ was $\alpha=39^{\circ}$, the height difference from the release area to the end of the runout zone $450 \mathrm{~m}$, and the runout distance about $300 \mathrm{~m}$ with an average slope inclination of $33^{\circ}$. If the $\alpha$ value were transferred to the terrain profile of Triftgletscher, the ice mass would easily reach the lake. The mean height of the avalanche deposit at Mattmark varied between $8 \mathrm{~m}$ and $10 \mathrm{~m}$. The comparison confirms that ice avalanches with volumes greater than $1 \cdot 10^{6} \mathrm{~m}^{3}$ will flow into the lake.

\section{Hydraulic study}

The impact of the ice avalanche plunging into a lake induces a so-called impulse wave. The generation of such a wave is subject to a nonlinear, three-dimensional process which comprises a highly unsteady three-phase flow (air, water, solids). The momentum transfer from the avalanche to the water body determines amplitude and length of the wave. Although this phenomenon has been under investigation for more than a century (Russel, 1844; Zweifel et al., 2006), it is not yet fully understood and its correct numerical simulation still poses a real challenge.

In the case of Triftgletscher, the generation and propagation of impulse waves were simulated based on a depthaveraged two-dimensional shallow water model (Fäh, 1996). To investigate the prognostic ability and the sensitivity of the numerical scheme, we performed a comparison with results from laboratory experiments dealing with the impact of a 
Table 5. Results of the avalanche dynamics calculations for different scenarios and surface geometries of Triftgletscher in 2003 and 2008 ( $V_{\text {aval }}$ : total ice avalanche volume, $V_{\text {aval-lake }}$ ice avalanche volume reaching the lake, vel $l_{\max }$ and $d_{\max }$ : velocity and flow depth of the avalanche entering in the lake).

\begin{tabular}{|c|c|c|c|c|c|c|}
\hline \multirow[t]{2}{*}{ Year } & \multirow[t]{2}{*}{$\begin{array}{r}V_{\text {aval }} \\
\left(10^{6} \mathrm{~m}^{3}\right)\end{array}$} & \multicolumn{2}{|c|}{$\begin{array}{l}\text { Friction } \\
\text { values }\end{array}$} & \multicolumn{2}{|c|}{$\begin{array}{l}\text { Parameters } \\
\text { at lake }\end{array}$} & \multirow[t]{2}{*}{$\begin{array}{r}V_{\text {aval-lake }} \\
\left(10^{6} \mathrm{~m}^{3}\right)\end{array}$} \\
\hline & & $\mu$ & $\xi\left(\mathrm{m} \mathrm{s}^{-2}\right)$ & $\operatorname{vel}_{\max }\left(\mathrm{m} \mathrm{s}^{-1}\right)$ & $d_{\max }(\mathrm{m})$ & \\
\hline 2003 & 0.2 & $0.35 / 0.20$ & $1000 / 1750$ & 9.6 & 0.2 & - \\
\hline 2003 & 1 & 0.2 & 1750 & 41.0 & 6.8 & $0.5-0.8$ \\
\hline 2003 & 5 & 0.2 & 1750 & 62.8 & 25.8 & $4.0-4.5$ \\
\hline 2008 & 0.1 & $0.35 / 0.20$ & $1000 / 1750$ & 4.0 & 0.3 & - \\
\hline 2008 & 1 & 0.2 & 1750 & 48.5 & 7.5 & $0.6-0.9$ \\
\hline 2008 & 2.5 & 0.2 & 1750 & 59.3 & 14.5 & $2.0-2.4$ \\
\hline 2008 & 5 & 0.2 & 1750 & 66.9 & 27.4 & $4.3-4.8$ \\
\hline
\end{tabular}

granular landslide on a water body (Zweifel et al., 2006). A close agreement between the computed flood trace (the envelope of the amplitude peaks) and the measured values was found. The wave generation due to the impact of the ice avalanche into the lake was modelled with a rigid body immersing into the lake. The form and propagation speed of the body was taken according to the resulting velocities and snow heights of the avalanche as they were determined in the avalanche dynamics study. The front speed of the virtual body was reduced linearly from the maximum at the beginning of the lake to zero within the immersion time. The length of the runout zone in the lake was chosen so that the displacement of water corresponds to the submerged ice volume. In the simulation model these boundary conditions were implemented by moving the bottom in space-time.

Figure 13 shows the simulated discharge in the canyon immediately beyond the lake (position A in Fig. 1) and $800 \mathrm{~m}$ downstream (position B in Fig. 1) for ice avalanches of 1 and $5 \cdot 10^{6} \mathrm{~m}^{3}$. Immediately beyond the lake, Triftwasser flows in the $300 \mathrm{~m}$ long canyon. Afterwards, the surface topography bordering the river is flat, causing a strong dampening effect on the flood wave. At the entrance to the canyon (riegel), immediately past the lake, the wave is retained and reflected on the rock wall. Due to the run-up, for an ice release of $5 \cdot 10^{6} \mathrm{~m}^{3}$, the water level is expected to rise up to $13 \mathrm{~m}$ above the lake surface in the canyon. After 6 min of propagation, the amplitude of the impulse waves is reduced by $90 \%$, but the lake water level remains above its normal value due to the water displacement of the submerged ice volume. A slow decrease in the lake level follows, since the corresponding water is progressively drained through the canyon. In the worst case scenario, the peak discharge of the first wave amounts to $3,000 \mathrm{~m}^{3} \mathrm{~s}^{-1}$. Whereas the period of this wave is only $37 \mathrm{~s}$, the transported water volume is so small $\left(45000 \mathrm{~m}^{3}\right)$ that it is spread out over the plateau after the canyon causing only a wetting of this area but no relevant peak discharge. The impact of the ice avalanche induces seiches (standing waves) in the lake. When the waves after the run-up at the "riegel" swash back, the water level falls below the bottom of the outflow slot leading to intermittent releases of water from the lake. After $180 \mathrm{~s}$ the superposition of the different order of waves and its damping due to the bottom friction causes the lake level to stay persistently higher than the bottom of the outlet. The corresponding continuous outflow is the relevant one for the delimitation of the flooded area in the Gadmertal. The amount of discharge is controlled by the bottleneck effect in the canyon. After position B, the flood propagates through a steep and narrow $4.5 \mathrm{~km}$ long valley until it reaches the endangered areas in the Gadmertal after 11 min. Here, a discharge of $400 \mathrm{~m}^{3} \mathrm{~s}^{-1}$ is expected for an initial release of $5 \cdot 10^{6} \mathrm{~m}^{3}$ of ice, corresponding to the eightfold of the peak discharge ever recorded at this location.

\section{Flow velocities monitoring}

It is likely that ice avalanches from cold hanging glaciers can be predicted with some success. However, prediction of avalanches that release from temperate ramp-type glaciers is more problematic and presently unattainable (Pralong et al., 2005; Pralong and Funk, 2006). Although high rates of sliding have been observed prior to the break-off and are likely to be necessary for such an event to occur, experience from Allalingletscher indicates that accurate prediction of catastrophic release is not yet possible. On the other hand, experience indicates that the hazard is small during the quiescent phase, which extends roughly from November to May. Large ice avalanches occur only during a period of enhanced sliding (the active phase), which appears to be limited to a few weeks during the late melt season (June-October). However, in view of the uncertainties concerning the mechanisms and controls on fast sliding, even this constraint must be viewed very cautiously. Nevertheless, early detection of an active phase can give an indication of a possible catastrophic release. On Allalingletscher, one of the monitoring methods 


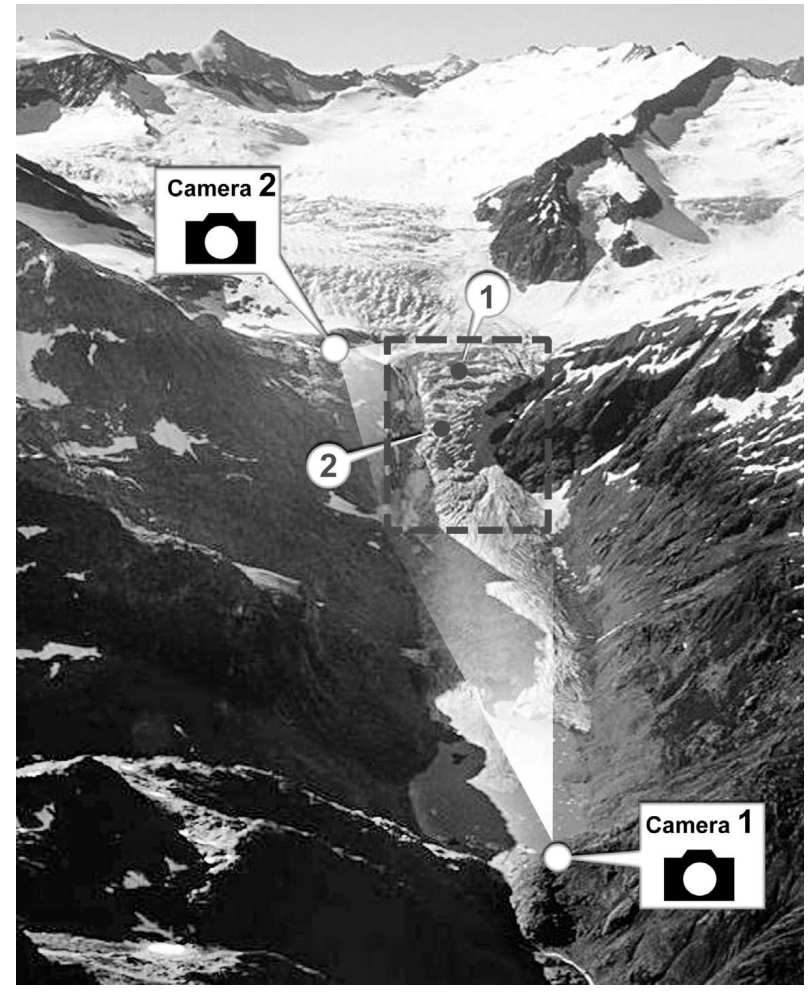

Fig. 14. Triftgletscher and locations of the two automatic cameras. The critical steep glacier sector is marked by the box. Time series of surface motion were determined for the points 1 and 2 .

consisted of aerial surveys repeated at short time intervals (one to two weeks) with subsequent photogrammetric processing to obtain flow velocities. With the other method, survey markers were installed directly on the glacier and regularly surveyed with a theodolite. While good results could be obtained with the first method, the second one proved difficult due to frequent loss of the markers. In any case, the total costs of the photogrammetric method are too high to be applied over long periods. However, the start of an active phase can be recognized with an adequate monitoring system for the surface motion of the critical zone. Although this approach does not allow a precise forecast of the release, it does at least enable the critical period to be identified within a few days. For Triftgletscher, its evolution is monitored by means of two automatic digital cameras installed in front and beside the critical part (Fig. 14). Camera 1 covers mainly the lower part of the steep glacier section, while camera 2 covers the upper part. Both cameras are remotely operated and equipped with a data-transmitting device (http://www.alpug.ch). Pictures have been taken once a day since 2004. On the basis of these pictures, the flow velocities in the steep glacier part are determined.

The flow velocities computation was performed using a sophisticated image-processing method called Digital Image Correlation (Chao and Sutton, 1993, implemented in the software VEDDAC). Digital Image Correlation (DIC) applied to digitized grey scale patterns is an optical field measuring method based on digital image acquisition and image processing. Digitized images acquired from the object under investigation at a reference state and, at least, one different state are compared using a special algorithm (Dost et al., 2003). An additional subpixel algorithm enhances the lateral resolution to approximately $1 / 10$ to $1 / 100$ of an image point (Pixel).

Seasonal changes in the glacier flow velocity (Fig. 15), and a typical flow velocity profile at its surface (Fig. 16) can be inferred from the DIC results. The velocity analysis is performed at least 3 times a month (depending on visibility conditions) and the associated accuracy is roughly $\pm 5 \mathrm{~cm}$. The first interesting results concerns the ability of the method to describe surface motion in chaotic areas such as the Triftgletscher seracs fall. We see on Fig. 16 surface motion during a week in late summer 2005, with values running from 0 to 10 pixels per 7 days. Their spatial distribution emphasizes the breaking-off of the slope well, with lower values upstream and bigger values in the middle dowstream. It was also possible to observe and detect potential significant disorders (Fig. 15) on a daily basis during summer and thus ensure early warning against contingently dangerous behavior of the Triftgletscher. During the $5 \mathrm{yr}$ of monitoring, the peak velocities around June-July decreased from $0.9-1.1 \mathrm{~m} \mathrm{~d}^{-1}$ in 2005 to $0.6-0.7 \mathrm{~m} \mathrm{~d}^{-1}$ in 2008 and 2009. During the other months, the flow speed did not change significantly and amounted to $0.4 \mathrm{~m} \mathrm{~d}^{-1}$ on average. Spectacular active phases with an order-of-magnitude flow velocity increase as observed on Allalingletscher have not been recorded so far.

\section{Conclusions}

The recent changes in Triftgletscher demonstrate nicely that a previously harmless glacier could become a serious hazard within a few years. There is, in fact, no historical record of any damage caused by flooding from the Triftwasser. However, the area of the newly formed proglacial lake has probably already been ice free in historic times during periods of glacial recession (Joerin et al., 2006). Although very rare in the Swiss Alps, large extent break-offs of steep temperate glaciers have occurred at other glaciers with a similar topography, such as Allalingletscher.

Results from our models indicate that without calving it would have taken $2 \mathrm{yr}$ longer for the lake to form than what was observed. They also indicate that the conditions for sudden release of a large ice mass $\left(1\right.$ million $\mathrm{m}^{3}$ or more $)$ are given for Triftgletscher. Numerical simulations of ice avalanche dynamics and of the generation as well as the propagation of the subsequent impulse wave show that damage is only to be anticipated in Gadmertal if the released ice volume exceeds 1 million $\mathrm{m}^{3}$. In this case, the flood wave is likely to reach the valley $11 \mathrm{~min}$ after the release. Triftgletscher is expected to retreat beyond the steep zone within the next two 

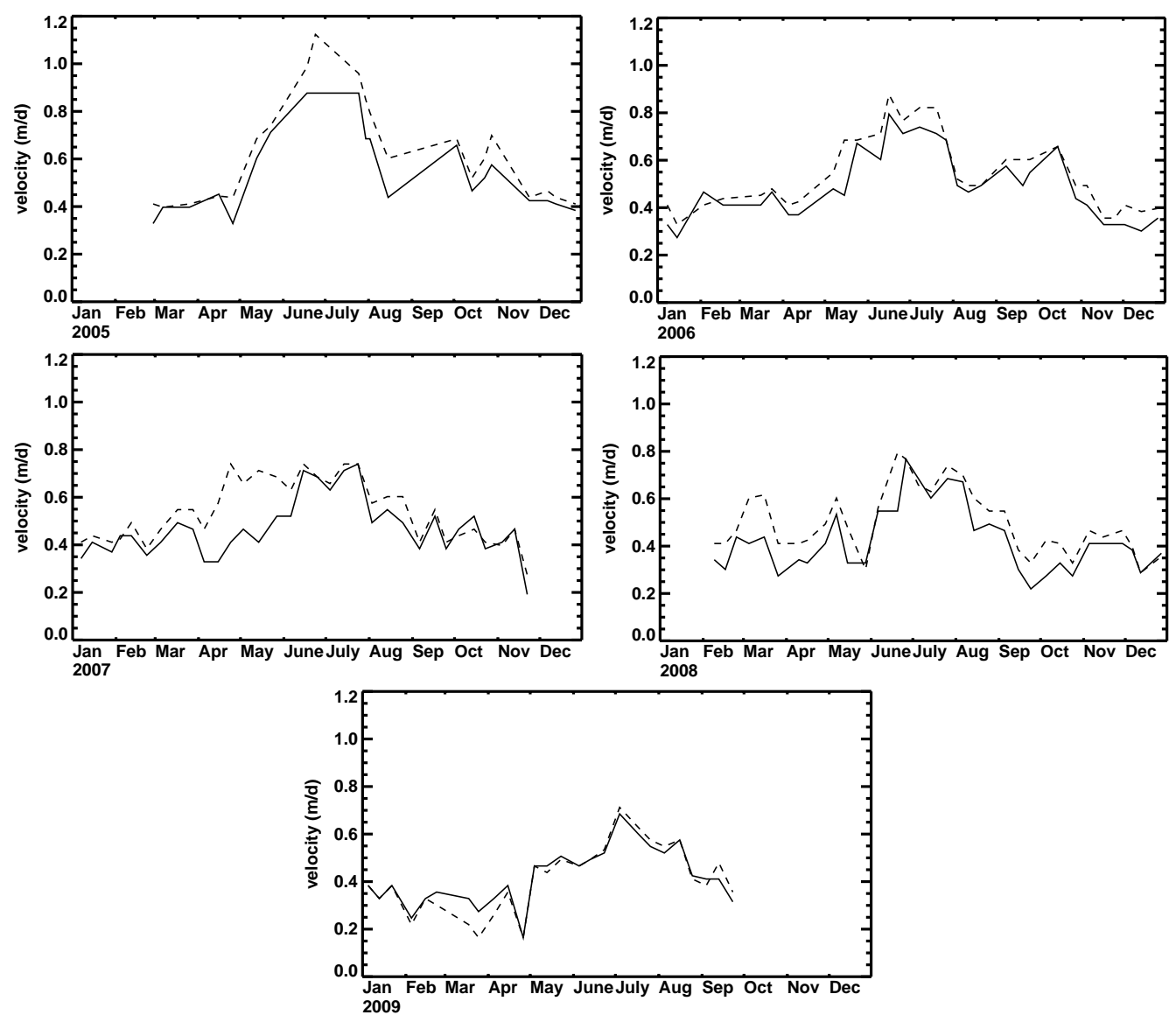

Fig. 15. Flow velocities for two points in the steep part of Triftgletscher from 2005 to 2009 (dashed line: point 1; solid line: point 2, see Fig. 14).

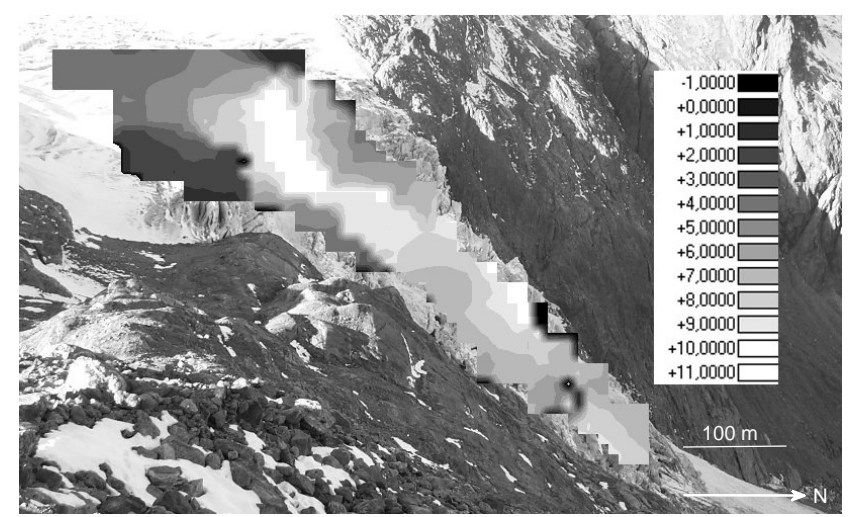

Fig. 16. Surface flow velocity field for Triftgletscher inferred from pictures taken with the upper camera: image-related displacements during a week in late summer 2005 in grey-coded representation (displacements in pixels/7 days).

decades under the present climatic conditions (Müller, 2004). This means that the hazard of dangerous ice avalanches will persist as long as the critical ice volume $\left(10^{6} \mathrm{~m}^{3}\right)$ in the steep zone is exceeded. The measured surface motion time series over the last $5 \mathrm{yr}$ show that they increase in summer to double the winter season values, but in comparison to the observed velocity changes at Allalingletscher, where the surface motion increased from $0.1 \mathrm{~m} \mathrm{~d}^{-1}$ to several $\mathrm{m} \mathrm{d}^{-1}$ within 2-3 weeks, the observed velocity increases at Triftgletscher are small. However, in view of the poorly known controls and mechanisms of the release of substantial parts of temperate ramp-type glaciers, there are no rigorous criteria indicating whether an important icefall is imminent. With regard to the uncertain early warning signs in the case of Triftgletscher, a safest hazard mitigation strategy is necessary.

Acknowledgements. This work has been supported by the EU-FP7 "ACQWA" Project (www.acqwa.ch) under Contract Nr 212250. It is a result of hazard assessment efforts conducted at the request of the Canton of Berne. Thanks are due to Hermann Bösch for preparing all the DEMs and orthophotos. We also thank Swisstopo and R. Hübscher for the aerial photographic surveys. We are indebted to H. Gubler (ALPUG, Davos) for the design and construction of the automatic cameras, to the reviewers Roman Motyka and Jaume Bordonau for the helpful comments and to Susan Braun-Clarke who proofread the English. The close collaboration 
with the company GEOTEST (Zollikofen, Berne), in particular with H. Keusen, is also gratefully acknowledged. This work is dedicated to Boris Müller who died in the mountains shortly after completion of his diploma thesis on the topic of Triftgletscher.

Edited by: J. Manuel Vilaplana

Reviewed by: J. Bordonau and R. J. Motyka

\section{References}

Alean, J.: Untersuchungen über Entstehungsbedingungen und Reichweiten von Eislawinen, Mitteilung 74, Versuchsanstalt für Wasserbau, Hydrologie und Glaziologie der ETH Zürich, 1984.

Bartelt, P., Salm, B., and Gruber, U.: Calculating the densesnow avalanche runout using a Voellmy-fluid model with active/passive longitudinal straining, J. Glaciol., 145, 242-254, 1999.

Bauder, A., Funk, M., and Huss, M.: Ice volume changes of selected glaciers in the Swiss Alps since the end of the 19th century, Ann. Glaciol., 46, 145-149, 2007.

Boyce, E. S., Motyka, R. J., and Truffer, M.: Flotation and retreat of a lake-calving terminus, Mendenhall Glacier, southeast Alaska, USA, J. Glaciol., 53, 211-224, 2007.

Chao, Y.-J. and Sutton, M. A.: Accurate Measurement of Twoand Three-Dimensional Surface Deformation for Fracture Specimens by Computer Vision, in: Experimental techniques in fracture, edited by: Epstein, J. S., 59-93, VCH Publishers, Inc., New York, 1993.

Christen, M., Bartelt, P., and Gruber, U.: An Avalanche Dynamics Program for the Practice, in: Proc. INTERPAEVENT 2002 in the Pacific Rim - Matsumoto, Oct. 14-18, 2, 715-725, 2002.

Dost, M., Vogel, D., Winkler, T., Vogel, J., Erb, R., Kieselstein, E., and Michel, B.: How to Detect Edgar Allan Poe's "purloined letter"-or: Cross correlation algorithms in digitised video images for object identification, movement evaluation and deformation analysis, in: P Soc Photo-Opt Ins, SPIE, Bellington, WA, 5048, 2003.

Fäh, R.: Erosion-based dambreak simulation, in: Proc. Second Int. Conference on Hydroinformatics, Zurich, 96, 681-688, 1996.

Farinotti, D., Huss, M., Bauder, A., and Funk, M.: An estimate of the glacier ice volume in the Swiss Alps, Global. Planet. Change, 68, 225-231, doi:10.1016/j.gloplacha.2009.05.004, 2009.

Grischott, R., Anselmetti, F., and Funk, M.: Seismic Survey Lake Trift, Tech. rep., Eawag Dübendorf and VAW Zürich, (unpublished), 2010.

Hock, R.: A distributed temperature-index ice- and snowmelt model including potential direct solar radiation, J. Glaciol., 45, 101$111,1999$.

Huss, M., Bauder, A., and Funk, M.: Homogenization of long-term mass-balance time series, Ann. Glaciol., 50, 198-206, 2009.

Joerin, U. E., Stocker, T. F., and Schlüchter, C.: Multicentury glacier fluctuations in the Swiss Alps during the Holocene, Holocene, 16(5), 697-704, 2006.
Margreth, S. and Funk, M.: Hazard mapping for ice and combined snow/ice avalanches - two case studies from the Swiss and Italian Alps, Cold. Reg. Sci. Technol., 30, 159-173, 1999.

Meier, M. F. and Post, A.: Fast Tidewater Glaciers, J. Geophy. Res., 92, 9051-9058, 1987.

Müller, B.: Veränderung am Triftgletscher seit 1861: Untersuchung der Stabilitätsveränderung der Steilstufe, Diplomarbeit an der VAW/ETH-Zürich, (unpublished), 2004.

Ohmura, A.: Physical basis for the temperature-based melt-index method, J. Appl. Meteorol., 40, 753-761, doi:10.1175/15200450, 2001.

Paterson, W. S. B.: The Physics of Glaciers, Pergamon, New York, 3rd Edn., 1994.

Pralong, A. and Funk, M.: On the instability of avalanching glaciers, J. Glaciol., 52, 31-48, 2006.

Pralong, A., Birrer, C., Stahel, W. A., and Funk, M.: On the predictability of ice avalanches, Nonlin. Processes Geophys., 12, 849-861, doi:10.5194/npg-12-849-2005, 2005.

Raymond, M., Wegmann, M., and Funk, M.: Inventar gefährlicher Gletscher in der Schweiz, Mitteilung 182, Versuchsanstalt für Wasserbau, Hydrologie und Glaziologie der ETH Zürich, 2003.

Röthlisberger, H.: Eislawinen und Ausbrüche von Gletscherseen, in: P. Kasser (Ed.), Gletscher und Klima - glaciers et climat, Jahrbuch der Schweizerischen Naturforschenden Gesellschaft, wissenschaftlicher Teil 1978, Birkhäuser Verlag Basel, Boston, Stuttgart, 170-212, 1981.

Russel, J.: Report on waves, in: Report of the 14th Meeting of the British Association for the Advancement of Science, York, 311390, 1844.

Salm, B., Burkard, A., and Gubler, H. U.: Berechnung von Fliesslawinen. Eine Anleitung für den Praktiker mit Beispielen., Tech. rep., Eidg. Institut für Scnee- und Lawinenforschung, SLF, Davos, 1990.

Thibert, E., Blanc, R., Vincent, C., and Eckert, N.: Glaciological and volumetric mass-balance measurements: error analysis over 51 years for Glacier de Sarennes, French Alps, J. Glaciol., 54(186), 522-532, doi:10.3189/002214308785837093, 2008.

Vallon, M.: Evolution, Water Balance, Potential Hazards and Control of a Pro-glacial Lake in the French Alps, Ann. Glaciol., 13, 273-278, 1989.

Van der Veen, C. J.: Tidewater calving, J. Glaciol., 42, 375-385, 1996.

Vieli, A., Funk, M., and Blatter, H.: Flow dynamics of tidewater glaciers: a numerical modelling approach, J. Glaciol., 47, 595606, 2001.

Vincent, C.: Influence of climate change over the 20th Century on four French glacier mass balances, J. Geophy. Res., 107, 4375, doi:10.1029/2001GL014592, 2002.

Vivian, R.: Des Glaciers du Faucigny aux Glaciers du Mont- Blanc, La Fontaine de Siloé, Couvent des Dominicains, Vieille Rue, 73801 Montmélian, cedex, 2001.

Warren, C., Benn, D., Winchester, V., and Harrison, S.: Buoyancydriven lacustrine calving, Glaciar Nef, Chilean Patagonia, J. Glaciol., 47, 135-146, 2001.

Zweifel, A., Hager, W., and Minor, H.: Plane impulse waves in reservoirs, J. Waterw. Port. C-Asce., 132, 358-368, 2006. 